\title{
Targeting the Most Harmful Co-Offenders in Denmark: a Social Network Analysis Approach
}

\section{Christian Frydensberg, et al. [full author details at the end of the article]}

Published online: 8 May 2019

(C) The Author(s) 2019

\section{Abstract}

Research Question Is there a 'power few' individuals in Denmark who, through consistent co-offending, produce the highest frequency of crimes and the most harm to society amongst all co-offenders?

Data We analysed official statistics from the Police Crime Case Management System in Denmark on all 437,717 charges for violations of the Danish Criminal Code, the Illegal Substances Act and the Weapons Act, in which co-offender relationships were identified from 2007 to 2017 , equal to $28 \%$ of the national total of all 1,554,943 such charges filed against both solo offenders and co-offenders in that time period.

Methods We cross-referenced charging records with crime harm values taken from the Danish Crime Harm Index to measure the severity of all offence types charged. A social network analysis (SNA) algorithm was applied to the data to test for centrality and identify key co-offenders.

Findings While $7.5 \%$ of the co-offending population accounted for $50 \%$ of crime volume, only $3.6 \%$ of the co-offenders accounted for $50 \%$ of total crime harm. The latter made up just $1.2 \%$ of the overall offender population in Denmark, but contributed $24 \%$ of overall harm. Social network analysis of how central that power few was in relation to other cooffenders suggests an even smaller cohort of co-offenders - the 'power few of the power few' - who are disproportionality more connected to other co-offenders.

Conclusions The 'power few' phenomenon exists in co-offender networks, with a pronounced concentration of harm caused by a small number of co-offenders. The evidence suggests that targeting co-offenders based on social network analysis can enhance the harm potentially reduced by both investigations and crime prevention strategies.

Keywords Co-offenders $\cdot$ Crime harm $\cdot$ Power few $\cdot$ Targeting $\cdot$ Social network analysis

\section{Introduction}

Evidence-based targeting aims to find the most efficient and cost-effective allocation of police resources. A process of prioritising resources - or triaging - can be more transparently justified based on clear evidence than on subjective preferences. Numerous evidencebased targeting strategies have emerged in recent years, establishing one clear and consistent 
theme: not all crimes or criminals are equally harmful (Sherman et al. 2016). The evidence points to a clear "Pareto curve" phenomenon: not only are most criminal events attributable to a small group of people, places or times (Sherman 2007); so, too, is most crime harm concentrated in a small percentage of places (Weinborn et al. 2017), victims (Dudfield et al. 2017) and victim-offenders (Sandall et al 2018).

In this article, we present what may be the first published evidence on the disproportionate concentration of harm amongst a unit of analysis previously uncharted for harm: cooffenders. Co-offending is a widespread characteristic of criminal events (Reiss Jr. 1988), yet policing scholars have generally ignored its potential for targeting. For example, group size alone was found to predict the harm caused by organised crime groups and gang members in the West Midlands, UK (Denley and Ariel 2019). Similarly, based on data on co-offending networks compiled from intelligence records in London, it is evident that co-offending is a strong correlate of future offending (Linton 2016). Co-offenders were also found to produce substantially higher levels of crime counts compared with 'solo' offenders in Sacramento, California (e.g. Englefield and Ariel 2017). Despite this growing body of evidence, we suspect that most police departments do not (yet) strategically target co-offenders. Rather, they often seem to guide their activities on the basis of tactical opportunities and ad hoc operations (Cornish and Clarke 2002, pp. 55-57).

To address the gap in the literature about the harm composition generated by cooffending networks, we have analysed police charging records in Denmark. Currently, the Danish Police force identifies offenders who will be subjected to prioritised targeting based on a variety of factors, including the number of prior offences, but especially crimes indicating their role in a criminal network (gangs, organised crime groups, etc.). These offenders are 'on-boarded' for police interventions based purely on professional judgement tools, including the Canadian SLEIPNIR method (Strang 2009), rather than on the basis of an actuarial, systematic approach to triaging. Despite the accumulated evidence on poor predictive accuracy of professional judgement (see, for example MacBeth and Ariel 2017; Sutherland and Angel 2019), more evidence is clearly necessary in each domain of police targeting.

\section{Research Questions}

Our study therefore aims to explore a potential solution to this issue by applying the concept of the 'power few' to a database of co-charged offenders in Denmark. In this regard, we are primarily interested in two issues related to co-offending patterns:

1. To what extent are volume of crime and crime harm concentrated amongst populations of co-offender relationships?

2. What does social network analysis (SNA) tell us about the distribution of harm within populations of co-offenders?

\section{Co-offending}

The term 'co-offending' (Reiss Jr. 1988) is used to identify different types of relationships between offenders in groups of two or more, including gangs and organised crime 
networks (Carrington 2002). We should emphasise that gang-related and organised crime represents a small proportion of all crimes that are committed by co-offenders (Englefield and Ariel 2017). Co-offending represents a wide range of 'criminal enterprises', and not just well-organised groups. It includes any crimes in which people offend in cooperation with others (McGloin et al. 2008). This means that co-offending groups vary in group size, longevity of the group and the extent to which they are specialists or diverse in their criminal portfolio (Lantz and Hutchison 2015; Sorensen 2009; Warr 1996). The term can also cover the execution of both simple and complex crimes, including those for which special skills are required (Weerman 2003).

There are different findings on the prevalence of co-offending in society between studies using police-records and studies using self-reported offending. Warr (1996) looked at self-reported offences drawn from the National Survey of Youth; he found that $73 \%$ of self-reported delinquent acts involved co-offending. In contrast, police records studied by Carrington (2002) and Van Mastrigt and Farrington (2011) found that no more than $15 \%$ of offences involved multiple offenders. Any study that relies on official statistics alone necessarily misses the majority of crime incidents because much of the co-offending crime phenomenon is 'unknown' to the police. These findings remain useful, however, as the most systematic and reliable current data on cooffending networks for police targeting decisions.

Given the wide variability in the types of co-offending relationships that can exist, we also see evidence that co-offending is not equally distributed across crime types (McCarthy \& Hagan, 2001). Studies examining the distribution of co-offending across offence types have found that it is more prevalent in burglary and robbery, but violent offences are more likely to be solo-offences (Carrington 2002; Carrington and van Mastrigt 2013; Reiss and Farrington 1991; van Mastrigt and Farrington 2009). Juveniles are more likely to take part in co-offending behaviour than adults (McCord and Conway 2002).

\section{The 'Power Few' of the Targeting of the Most Harmful Offenders}

The concept of the 'power few' (Sherman 2007) takes its inspiration from the Pareto curve, a non-linear j-curve in which a small percentage of units in any given population accounts for any given characteristic of that particular population (Eck et al. 2007; Sherman 2007; Zipf 1949). Concentrations of crime in time, space and populations have been extensively documented (see Ariel and Partridge 2017; Weisburd and Mazerolle 2000; Weisburd and Eck 2004). These studies collectively show that a disproportionate amount of crime is committed/experienced by a relatively small number of units (Sherman et al., 1989; Sherman 2007). Limiting the number of potential units greatly increases our ability to then predict and potentially prevent future risk these power few units cause to society (see Zeng et al. 2017).

However, the overwhelming majority of studies that have investigated disproportionate crime concentrations have paid insufficient attention to the fact that not all crimes cause equal damage to victims (Sherman et al. 2016). Recently, analyses have emerged that consider these 'power few' concentrations through the lens of harm, rather than purely based on crime frequency or volume. As pointed out by Norton et al. (2018), a crime hotspot with 30 robberies in a given year is not the same as one with 30 thefts: the severity of these behaviours is not the same. In domestic violence studies, a 
very small subset of offenders has been found to cause the most harm to victims (Barnham, Barnes, \& Sherman, 2017; Bland and Ariel 2015). Dudfield et al. (2017) have shown that fewer than $5 \%$ of victims suffer $85 \%$ of the harm, with sex offences and robbery contributing almost two-thirds of total harm (63\%). Similarly, a small subset of organised crime groups (OCGs) and gangs produce the most harm where these groups operate (Denley and Ariel 2019). Again, in place-based studies, it has been shown that harm is more heavily concentrated than crime counts (e.g. Weinborn et al. 2017). Collectively, then, targeting these power few harmful units of analysis in a strategic way seems more useful than targeting concentrations of crime count volume without regard to harm.

There are different methods of defining or measuring harm. One method that has gained traction is the use of a crime harm index based on sentencing guidelines. The first systematic approach to use these metrics was the Cambridge Crime Harm Index (Sherman et al. 2016) - and soon, several conceptual and literal replications emerged since (e.g. Mitchell 2017; Ratcliffe 2015). Each crime event is multiplied by the number of prison days a firsttime offender would be sentenced to in court. The totals - or means per certain unit of measurement - can then be compared across places, individuals or groups of offenders. When the list of units is then rank-ordered based on frequency, the power few can then be identified, according to any parameter the researcher decides to use (e.g. two standard deviations from the mean, the top 5\%, the top 100).

In this study, we use a variation of the Cambridge Crime Harm Index developed in Denmark by Andersen and Mueller-Johnson (2018). This Danish Crime Harm Index (DCHI) uses data from the Danish Director of Public Prosecutions Office-which specify the (recommended) sentence that the prosecutor should ask for in court-while prosecuting a first-time offender in a case with no mitigating or aggravating circumstances. Like its Cambridge counterpart, the DCHI excludes police-discovered offences such as drug crimes, which are more commonly an indicator of police proactivity than harm. Andersen and Mueller-Johnson's (2018) analysis showed that theft and related offences - which represented $51 \%$ of all offences in 2016, in terms of volume - only accounted for $16 \%$ of inflicted harm. On the other hand, robbery only represented $1 \%$ of all offences in terms of volume, but $10 \%$ of harm.

\section{Co-offending and Social Network Analysis}

Social network analysis (SNA) is 'a way of thinking about social systems that focuses our attention on the relationships amongst the entities that make up the system, which we call actors and nodes' (Borgatti et al. 2013: p. 1). SNA examines the ties (relationships) between two (or more) nodes (actors) (Robins, 2015; Wasserman and Faust 1994). These ties between individuals tell us something about the people with whom an individual associates, and the focus or purpose of these ties (McGloin and Kirk 2010; Morselli et al. 2006).

There have been several studies that explore the utility of SNA in understanding cooffending populations. Research by McGloin and Kirk (2010) and Warr (2002) reveals that the number of co-offenders an offender is surrounded by is a powerful indicator of criminal behaviour; the more co-offenders to whom they are linked, the more 'centrality' they are said to have. Offenders generally co-offend with people they know, and actively seek out suitable candidates within their groups of associates (Warr 1996). 
Such relationships may be short-lived (Charette and Papachristos 2017). The most criminally active individuals, however, are also those with the highest level of centrality in a network (Haynie 2001; Lantz and Hutchison 2015).

Englefield and Ariel (2017) used SNA to explore the interconnectivity of groups of co-offenders, showing that some crime categories are more likely to see offenders engage in the recruitment of younger and less-experienced offenders - narcotics distribution and auto theft, for example. To this extent, SNA - as a conceptual as well as a technical approach - can be applied in the search for the most harmful power few offending networks in Denmark.

\section{Data and Methods}

\section{Data and Settings}

Denmark has one national police force that is divided into 12 territorial police districts. All registered offences in Denmark are recorded nationally in the Danish Police case management system, called POLSAS. For this study, we extracted from POLSAS all criminal charges under the Danish Criminal Code, the Illegal Substances Act and the Weapons Act in the 11 years between 2007 and 2017. The original dataset consisted of $1,554,943$ records, which we reduced to 437,717 by excluding charges for all offences in which only one person was charged with the offence, thus excluding charges that did not involve co-offending. The total number of charges involving co-offending compared with the total number of charges generated for solo- and co-offences is illustrated in Fig. 1. The total number of charges (solo- and co-offending) increased over the period studied, whereas the charges involving co-offending remained relatively consistent throughout the same period.

\section{Analytic Process}

Identifying the Harmful Power Few Co-Offenders We built on the DCHI (Andersen and Mueller-Johnson 2018) and developed a fit-for-purpose harm index, referred to as the

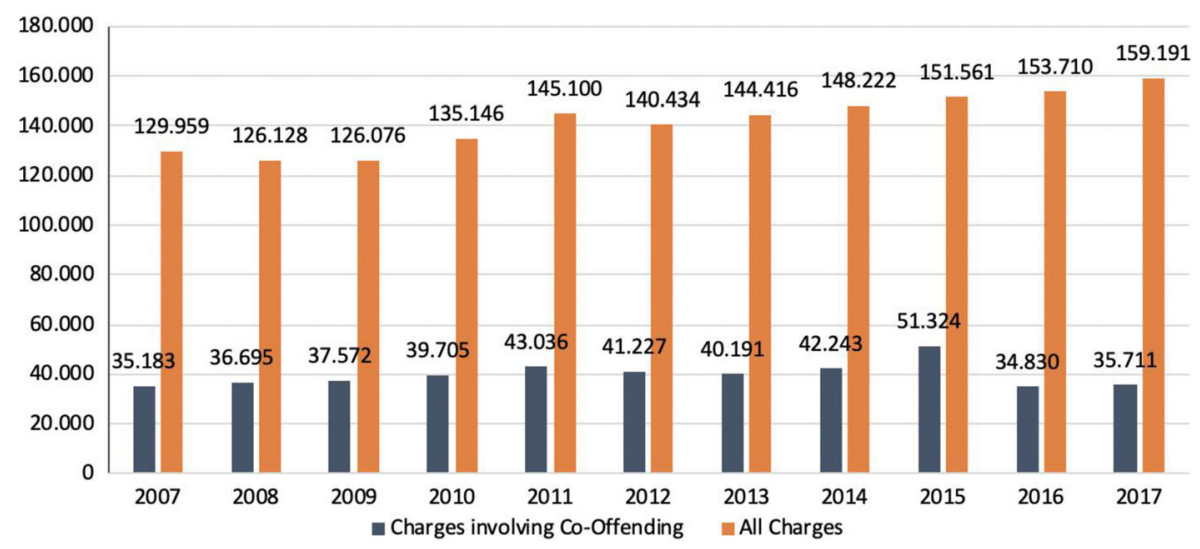

Fig. 1 Total number of charges involving both solo- and co-offending, 2007-2017 
Danish Offender Targeting Tool (DOTT). The DOTT uses the weightings established by the DCHI, but also computed new values for crime categories explicitly excluded from the DCHI model, particularly around more serious crime categories - drug offences and organised crime. We acknowledge the need to separate between policegenerated and public/victim-generated crime data. Because the measurement of the former is driven by enforcement policies, it does not constitute a measure of the rate of these crime categories (e.g. drug-dealing) in the population. Nonetheless, much of the targeting of potentially harmful offenders and co-offenders incorporates serious offences associated with individual offenders, such as weapon violations, possession of large quantities of drugs or enslaving people in unreported cases of human trafficking. Therefore, we incorporated 19 additional police-discovered categories and created 12 new groupings based on offence type, to the existing 46 crime categories included in the original DCHI. Values from the resulting DOTT were then assigned to each charge case in the database.

In order to detect the 'power few', offenders who were charged in groups of two or more were identified based on the charging data. These co-offenders were then rankordered twice - once based on the total number of charges in their criminal records, and then again with the associated DOTT score they had accumulated for their crimes. The accumulated crime-volume and crime-harm scores across the co-offending population were then calculated to identify the power few population that generated $50 \%$ of the total number of harm incidents involving co-offenders. Our rationale here was based on the UK Home Office study of 2001, which identified around $10 \%$ of the offender population that generated $50 \%$ of the total number of offences (Home Office 2001). Other studies may, of course, consider other thresholds, depending on their research questions.

Social Network Analysis Due to computational limitations, SNA was conducted only on the co-offending network of the harmful power few co-offenders, rather than the entire population of co-offenders. We first isolated the power few crime-harm cohort and their co-offenders into a separate dataset. We then converted the charges data from a 'twomode' network to a 'one-mode' network. The conversion was done using a Pythonscript specifically created for this dataset. This conversion was necessary in order to apply the SNA algorithms correctly. If an SNA algorithm was applied to a two-mode network, it would have given the now-converted node a centrality score, thereby possibly identifying the wrong nodes as central actors on the network. As illustrated in Fig. 2, if two offenders commit the same offence, in a two-mode network, it would look as follows: offender 1 commits offence 3 together with offender 2 . However, in a one-mode network, the same offence is a link: offender 1 is directly linked to offender 2 .

The centrality measure known as 'betweenness centrality' was applied to identify the nodes with the shortest path to all other nodes in the network (Borgatti et al. 2013; Freeman 1977; Newman 2005; Tayebi et al. 2011). The higher the measured value, the more central the actor is in the network. Betweenness centrality is often used when attempting to identify gatekeepers in a network (Borgatti et al. 2013) - the individuals who link networks together through their offending patterns.

Following this step, we used i2 Analyst Notebook 9.1 to create cartographic network charts visualising the co-offending networks embedded in the dataset. The size of each node illustrates how well the node-or co-offender - is connected to the rest of the network: the larger the node, the better connected the node is. Figure 3 shows a section 

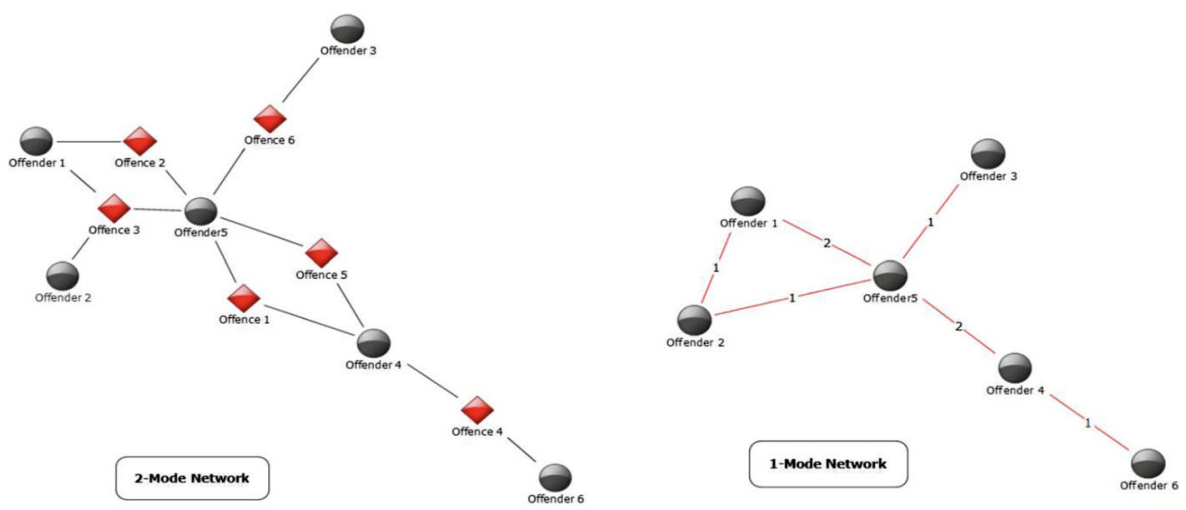

Fig. 2 Illustrated comparison of a two-mode network and one-mode network

of the main co-offending network. As can be seen, node \#1751 is larger than most of the other nodes, indicating that node \#1751 has the highest betweenness centrality score of the nodes seen in Fig. 3.

\section{Findings}

\section{'Power Few' Co-Offenders in Denmark Based on Crime Counts (Charges)}

We found that by counting the number of offences each co-offender in the dataset was charged with, a power few co-offending population of 8,832 offenders could be identified. This $7.42 \%$ of the co-offending population accounted for $49.99 \%$ of the 437,717 charges involving co-offending in Denmark in 2007-2017, according to charges data (Fig. 4).

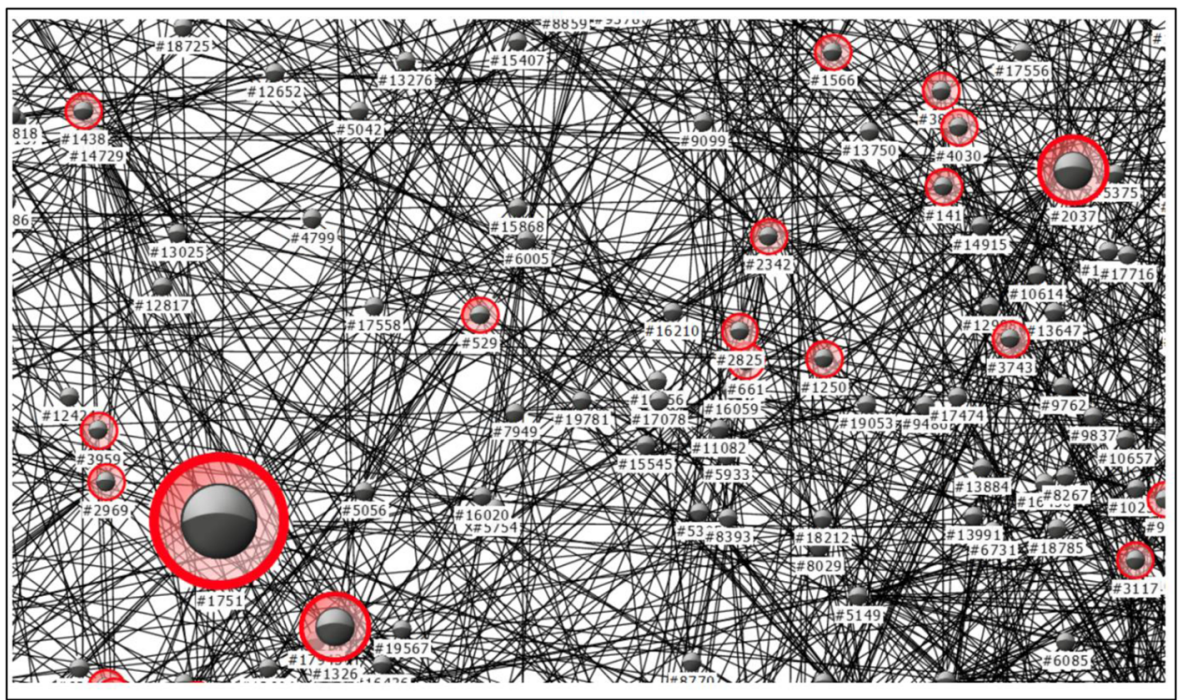

Fig. 3 Illustration of SNA with Denmark charge data: node size represents betweenness measure 


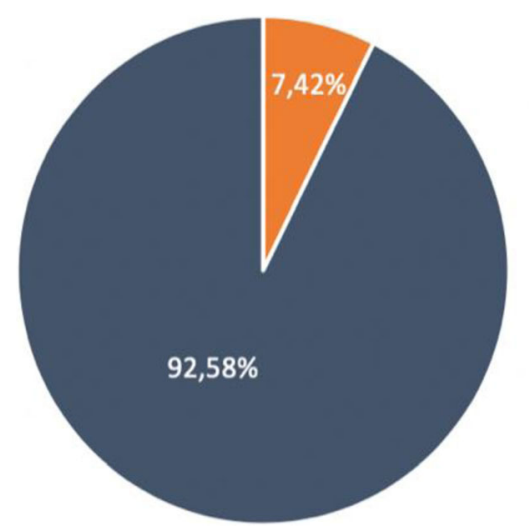

- Power Few

- Non Power Few

Fig. 4 The 'power few' co-offenders for count of crime

The gender composition across the total co-offending population, compared with the power few in terms of crime volume, showed a higher percentage $(91 \%)$ of males amongst the power few in terms of crime volume compared with the total co-offending population. Amongst the total co-offending population, $78 \%$ were identified as male and $22 \%$ as female, as shown in Fig. 5.

Of the 8,832 co-offenders identified as the 'power few' in terms of crime volume, $7.3 \%(n=648)$ were known to be members of an identified Organized Crime Group (OCG). Of these individuals, 206 were identified as members of street gangs, and 195 were members of one of the seven 'biker clubs' present in Denmark. Another 225 were members of OCGs not classified as street gangs or biker clubs. The remaining 22 were registered as associated to OCGs but not formally on the OCG members' registrar.

The power few were, on average, active for 3.78 years out of the 11 years studied in this dataset, almost identical with to the non-power few offending population's average of 3.68 years of activity. However, we found significant differences within the power few when gender was taken into account: male members of the power few were active for 3.87 years, compared with 2.86 years for the females.

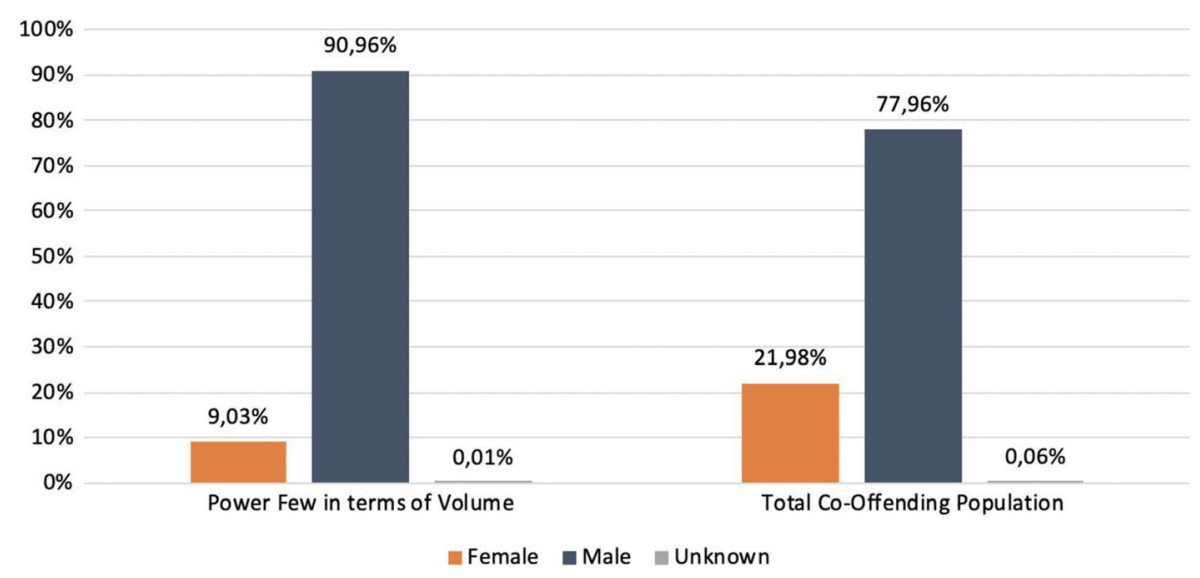

Fig. 5 Gender composition of co-offending count 'power few' compared with all co-offender population 
There were also no differences in the types of crime committed by the power few and non-power few co-offenders. The percentage of charges involving burglary $(15.30 \%$ vs. $19.88 \%)$ and theft $(29.76 \%$ vs. $35.02 \%)$ was somewhat higher for the power few co-offenders, but the proportion of charges involving violence/threats, homicide and sexual offences were all lower for the power few co-offending networks. This finding demonstrates that merely counting the number of offences, without taking the crime type into consideration, has limited value in the identification of the most harmful power few co-offending offenders.

Finally, we found that $7.42 \%$ of the co-offending population generated $14.0 \%$ $(n=61,325)$ of all the charges in Denmark in the period analysed-including charges with single offenders. As the volume of co-offending power few only consists of 8,832 offenders out of a total offender population of $357,215(2.5 \%)$ over the 11 years examined, we are able to use this analysis to generate suitable targets for future policing, as discussed below.

\section{'Power Few' Co-Offenders in Denmark Based on Crime Harm Index (DOTT)}

Based on the DOTT, the crime harm power few consists of 4,296 co-offenders out of the 119,069 co-offenders in the dataset. As illustrated in Fig. 6, this power few population equates to $3.61 \%$ of the entire co-offending population and generates $50 \%$ of the crime harm-comprising only half of the $7.42 \%$ of the co-offenders that produced the top $50 \%$ of crime counts.

The power few of harmful co-offenders is comprised of 4,013 males and 283 females. Of these, $13.2 \%(n=569)$ were recorded as members of an OCG; and, of that figure, 185 were identified as members of street gangs, 177 were members of one of the seven biker clubs in Denmark and 190 were members of OCGs not classified as street gangs or biker clubs. The remaining 17 were registered as associated to OCGs, with a larger proportion of the harm power few overall being found to be members of OCGs (see Fig. 7).

Of the 11 years studied in the dataset (2007-2017), the crime harm power few were active for an average of 3.68 years, with the majority of that population (79\%) active for between 1 and 5 years. This distribution of activities across the years studied was

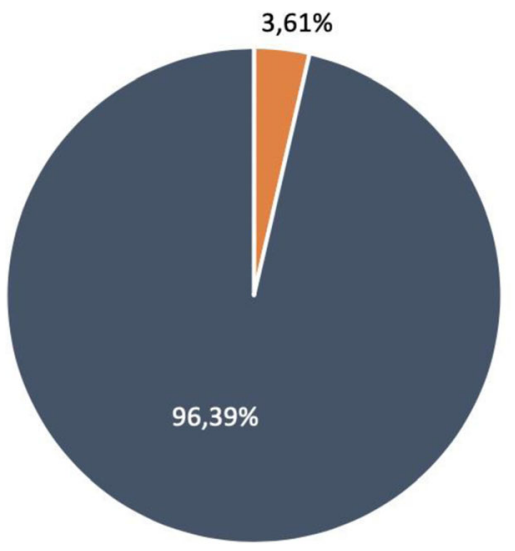

- Power Few

- Non Power few

Fig. 6 The 'power few' co-offenders for crime harm 


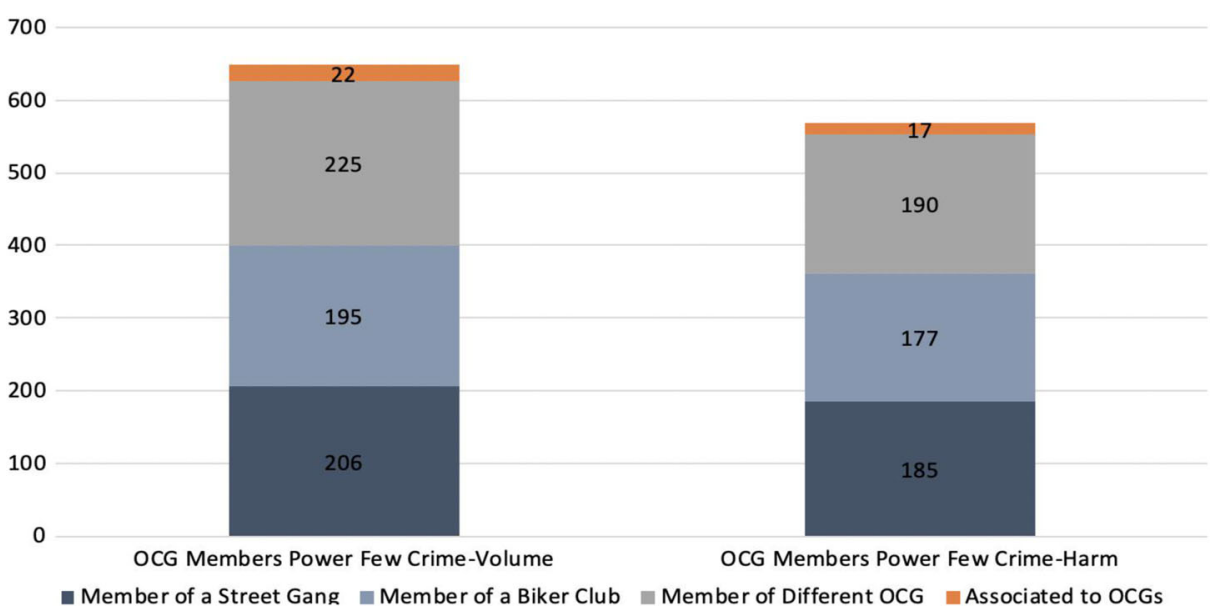

Fig. 7 Distribution of 'power few' co-offenders amongst OCGs

similar to the volume of the power few, and this was equally the case when the duration of activity was analysed by gender.

Figure 8 illustrates how the distribution of crime type changes when focusing on crime harm (measured by DOTT) instead of crime counts. While fraud/embezzlement accounted for more than $44 \%$ of all the charges, it generated just under $18 \%$ of crime harm. Crime types such as theft (15.6\%) and burglary (14.4\%) accounted for large percentages of the total number of charges generated by the power few in terms of crime counts. However, theft represented only $1.3 \%$ and burglary only $3.68 \%$ of the crime harm generated by the power few co-offenders. Homicide and robbery accounted for $2.5 \%$ and $6.7 \%$, respectively, of the charges generated, but homicide accounted for $26.7 \%$ and robbery $38.8 \%$ of the crime harm generated.

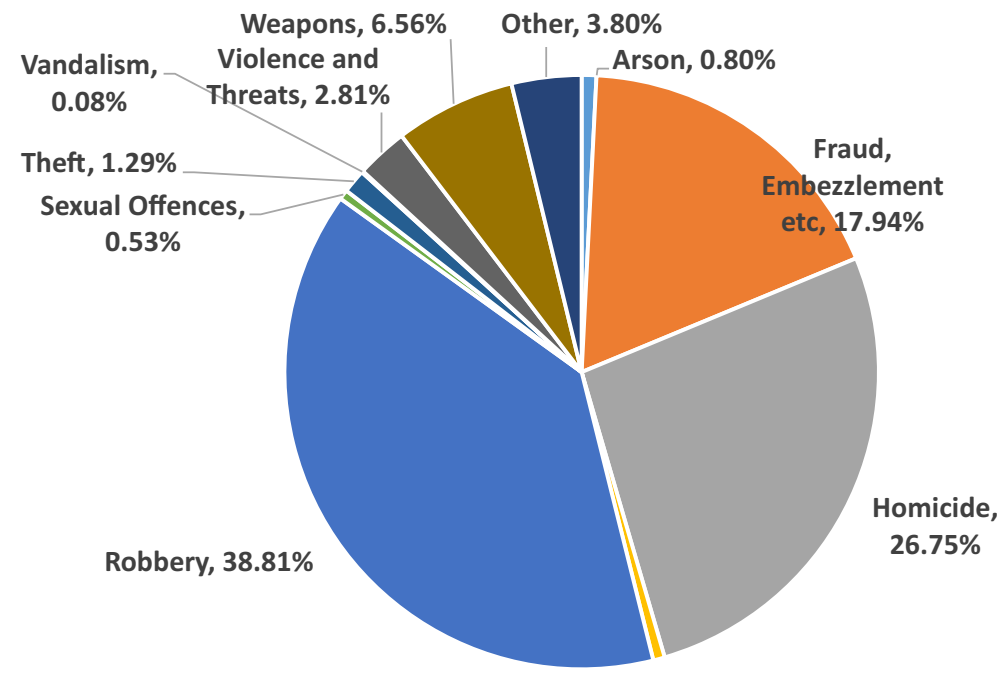

Narcotics, $0.63 \%$

Fig. 8 Distribution of DOTT harm by crime type amongst the harm-generating 'power few' co-offenders 
Overall, the harm-generating power few co-offender cohort made up $1.2 \%$ of all offenders in the database (including non-co-offenders), yet accounted for $23.6 \%$ of all charges. This group did not only co-offend with other offenders in the power few population but also with a large number of other co-offending partners. These cooffending partners, who made up $13.2 \%(n=15,748)$ of the co-offending population, contributed another $14.1 \%$ of the total crime harm generated by the co-offending population for a total contribution (charged and connected) of $64.1 \%$ of the total crime harm produced by the co-offending population.

\section{Social Network Analysis and Central Actors in the Co-Offending Networks}

The majority of the harm-generating power few co-offenders were connected in one main network that included many far less-harmful offenders. That network consisted of $82.4 \%$ of the power few population and $94.9 \%$ of all the co-offending population, across the 11 years studied. The remaining 757 co-offenders in the power few population and their 807 co-offending partners were found in isolated clusters and dyads. These isolated co-offenders had $75 \%$ more charges for fraud/embezzlement, 33\% more homicide charges and $55 \%$ more sexual offence charges than those connected to the main network. The connected co-offenders were more commonly engaged in arson, violence/threats and weapon offences.

We then applied the betweenness centrality measure to this network in order to further examine the benefit of focusing on the power few. We identified the nodes showing the shortest path to all other nodes in the network, and rank-ordered them by that measure. Table 1 presents the data on the top ten co-offenders, or the most interconnected power few. This subgroup of the network (2\%) is linked to 196 other power few co-offenders (44\%) and 241 co-offenders not within the power few. Figure 3 illustrates the connections of the top ten to other co-offenders. Our analysis showed that if the top ten were removed from the network, an additional 122 co-offenders would be isolated.

\section{Discussion and Conclusions}

Identifying the most harmful potential offenders for investigative and preventive targeting is routinely done without evidence-based tracking, let alone evidence-based selection. The approach we employ in this article may appear difficult and expensive, but that conclusion is not supported by the facts. What is expensive is investing substantial police resources in a medium-harm group of co-offenders, while very high-harm co-offenders are not targeted. What is difficult is to decide which offenders to target in the absence of evidence-based policing analyses.

As our tools develop, so does our ability to identify certain individuals in the offender population - the targeting of whom can lead to significant reductions in criminal behaviour (e.g. Barnes et al. 2017). Equally, the body of evidence on different units of targets - individuals, hotspots, facilities, etc.-is growing as well (see Ariel 2018; Ariel et al. 2015).

In this paper, we attempted to show two additional layers to this line of research. First, we offer an alternative perspective to the 'one-at-a-time' approach and focus 
Table 1 Top 10 co-offenders in the main network based on betweenness centrality (ten dyads)

\begin{tabular}{llllllll}
\hline Label & Gender & OCG member & Power few? & DOTT score & No. of charges & Years active & Betweenness \\
$\# 16338$ & M & No & No & 200 & 8 & 2 & 2,649311078 \\
$\# 2392$ & M & No & Yes & 11342 & 74 & 11 & 2,311751029 \\
$\# 1358$ & M & Yes & Yes & 6218 & 46 & 10 & 2,240080975 \\
$\# 3750$ & M & Yes & Yes & 2400 & 60 & 8 & 2,064896368 \\
$\# 17237$ & M & No & No & 186 & 8 & 2 & 1,848002641 \\
$\# 2230$ & M & No & Yes & 8284 & 64 & 9 & 1,681752448 \\
$\# 1128$ & M & Yes & Yes & 2450 & 44 & 10 & 1,665286143 \\
$\# 3926$ & M & No & Yes & 9062 & 38 & 10 & 1,632929609 \\
$\# 1897$ & M & No & Yes & 17264 & 155 & 9 & 1,607660439 \\
$\# 1751$ & M & Yes & Yes & 7216 & 49 & 9 & 1,596910151 \\
\hline
\end{tabular}

instead on co-offending networks; second, we echo the call for greater attention to measuring harm rather than counts of crime when determining the suitability of targets. So how can these findings help improve the ways in which the police identify offenders using an evidence-based approach?

\section{'Get Them in Packs'}

Targeting groups of two or more co-offenders, rather than individual offenders one at a time, would limit the total number of suitable targets in which the police invests. This compressed approach to targeting is not only efficient. It may also be more effective.

A growing body of research on peer influence and network communications is leading to a greater understanding of how sanction threat messages cascade through groups (Papachristos et al. 2015). The relevance of targeting is clear: people talk, and the police can leverage their talking. Assume a hypothetical police department identified actors within social networks of co-offenders who are responsible for transmitting messages to the group members. If the police targeted these key actors in the network by either a preventative or a pursuit exercise, it can be assumed that they would communicate their interaction with the police to other members of the network.

By targeting key actors, the effect exerted on those individuals may cascade into more of their co-offending parties than by contacting less 'central' co-offenders. Even though the police have not been directly involved with these co-offending parties, they may leverage them for sending effective messages, in a strategy of focussed deterrence (Braga and Weisburd 2012). By piggybacking on the social links offenders have with others, any police force can increase its crime-prevention utility by interacting with co-offenders with the view of preventing the criminal behaviour of others. So far, however, very little has been done through prospective and controlled studies (but see Ariel et al. 2019).

Given the ubiquity of the Pareto curve in criminal enterprises, it should be no surprise that we have identified, within the already over-represented population of co-offenders, a subgroup of co-offenders that produce disproportionally more crime than others. However, the results are still telling; these so-called 'power few' represent less than $8 \%$ of all co-offenders, but they produce half of all the charged crimes in Demark. Identifying these relationships-particularly the persisting co-offending 
relationships (Denley and Ariel 2019) — could lead to both more efficiency and effectiveness in utilisation of police resources. By rank-ordering the co-offending unitseither crudely by frequency and volume only, or conditional of other features that may explain more crime, such as age, betweenness, specialisation or persistency-the police can then strategically target the 'heavier' producers of crimes in society, and leverage their communications with associated offenders.

In this paper, we have demonstrated that SNA can be used to meaningfully narrow the co-offender population even further, by identifying key individuals whose cooffending interactions with other offenders classify them as central players in the cooffending network with which they are affiliated. The algorithms employed for these tasks are built into widely available analytical software and can be applied quickly and cheaply by police analysts. Such techniques offer much promise for the future of targeting analyses and provide many police departments with a ready-made opportunity to try big-data policies - especially when it comes to targeting criminal networks and the gatekeepers within these communities.

\section{Harm, Severity and Seriousness, But Not Counts}

Our second contribution is to expand the evidence on what a 'power few' in offending can mean, beyond frequency and counts of crimes. Unlike the pivotal studies by Morselli (2009), Morselli et al. (2006) and others who implemented count-based models to identify suitable targets in criminal networks, our study joins Sherman et al. (2016) to see a more weighted approach to identifying suitable targets based on the harm that they cause. Whereas previous studies necessarily focussed on the number of offences offenders commit, we focus on the severity harm.

In this study, we have found tangible evidence of a harm-generating power few that produce a substantial portion of the crime harm in Denmark. We have found that $3.6 \%$ of the co-offending population accounts for $50 \%$ the total harm, caused by that population, based on the DOTT harm index we applied.

These findings join other recent studies on the concentration of crime harm across different units of measurement. Collectively, the studies reviewed earlier suggest at least two conclusions. Firstly, crime harm is substantially more concentrated than crime counts; our findings show that this pattern is true for co-offending networks as well. When considering the 'power few of the power few' of harm, then the target list is shorter than any list of offenders who are rank-ordered by the frequency of crimes that they have committed. If the most harmful co-offenders can be identified, they may well be predicted. While description is never the same as prediction, it is a helpful first step. If just $1.2 \%$ of the overall offending population in Denmark contributed $24 \%$ of overall harm over 11 years, that pattern is a good place to begin predictive studies of who will cause the most harm next year. When we consider the list of offenders in Table 1, it becomes obvious that 'removing' just these 20 offenders could potentially isolate $27 \%$ of their co-offenders from the main network - suggesting a potential displaced value from selecting such individuals for priority targeting.

Finally, we are encouraged by the utility of SNA in the analysis of crime harm. As demonstrated in this article, it provides additional opportunities not just for tactical law enforcement decisions. It should also help criminologists and other scientists who are interested in expanding the scope of analysis on the ways in which co-offenders interact. 
Our focus on one large network in Denmark suggests that there is potential for dismantling the criminal behaviour of many actors at once. That potential comes from focusing solely on offenders who have committed crimes with an unusually high number of other co-offenders. Such an approach — testing the effect of cascading messages within groups - is a promising avenue for research, as well as for evidence-based policing.

Acknowledgements The first author is grateful to the Danish Police for selecting him to attend the Cambridge Police Executive Programme, where the present article was developed as an MSt thesis. He also wishes to thank the Trygfonden (Security Foundation) of Denmark for funding Danish Police employees to study in the Cambridge Police Executive Programme.

Open Access This article is distributed under the terms of the Creative Commons Attribution 4.0 International License (http://creativecommons.org/licenses/by/4.0/), which permits unrestricted use, distribution, and reproduction in any medium, provided you give appropriate credit to the original author(s) and the source, provide a link to the Creative Commons license, and indicate if changes were made.

\section{References}

Andersen, H.A. \& Mueller-Johnson, K. (2018). The Danish Crime Harm Index: how it works and why it matters. Cambridge Journal of Evidenced-based Policing.

Ariel, B. (2018). "Not all evidence is created equal": on the importance of matching research questions with research methods in evidence based policing. Evidence Based Policing: An Introduction, 63.

Ariel, B., \& Partridge, H. (2017). Predictable policing: measuring the crime control benefits of hotspots policing at bus stops. Journal of Quantitative Criminology, 33(4), 809-833.

Ariel, B., Weinborn, C., \& Boyle, A. (2015). Can routinely collected ambulance data about assaults contribute to reduction in community violence? Emergency Medicine Journal, 32(4), 308-313.

Ariel, B., Englefield, A., \& Denley, J. (2019). 'I heard it through the grapevine': a randomized controlled trial on the direct and vicarious effects of "preventative specific deterrence initiatives". Journal of Criminal Law and Criminology.

Barnes, G. C., Hyatt, J. M., \& Sherman, L. W. (2017). Even a little bit helps: an implementation and experimental evaluation of cognitive-behavioral therapy for high-risk probationers. Criminal Justice and Behavior, 44(4), 611-630.

Barnham, L., Barnes, G. C., \& Sherman, L. W. (2017). Targeting escalation of intimate partner violence: evidence from 52,000 offenders. Cambridge Journal of Evidence-Based Policing, 1(2-3), 116-142.

Bland, M., \& Ariel, B. (2015). Targeting escalation in reported domestic abuse: evidence from 36,000 callouts. International criminal justice review, 25(1), 30-53.

Borgatti, S. P., Everett, M. G., \& Johnson, J. C. (2013). Analyzing social networks. London: Sage Publications Ltd.

Braga, A. A., \& Weisburd, D. L. (2012). The effects of focused deterrence strategies on crime: a systematic review and meta-analysis of the empirical evidence. Journal of Research in Crime and Delinquency, 49(3), 323-358.

Carrington, P. J. (2002). Group crime in Canada. Canadian Journal of Criminology, 44, 277-315.

Carrington, P. J., \& van Mastrigt, S. B. (2013). Co-offending in Canada, England and the United States: a cross-national comparison. Global Crime., 14(2-3), 123-140 Routledge.

Charette, Y., \& Papachristos, A. V. (2017). The network dynamics of co-offending careers. Social Networks, 51, 3-13.

Cornish, D. B., \& Clarke, R. V. (2002). Analyzing organized crimes. In A. Piquero \& S. Tibbets (Eds.), Rational choice and criminal behavior: recent research and future challenges (pp. 41-63). New York: Routledge.

Denley, J., \& Ariel, B. (2019). Whom should we target to prevent? Analysis of organized crime in England using intelligence records. European Journal of Crime, Criminal Law and Criminal Justice, 27(1), 13-44.

Dudfield, G., Angel, C., Sherman, L. W., \& Torrence, S. (2017). The "power curve" of victim harm: targeting the distribution of crime harm index values across all victims and repeat victims over 1 year. Cambridge Journal of Evidence-Based Policing, 1(1), 38-58.

Eck, J., Clarke, R., \& Guerette, R. (2007). Risky facilities: crime concentrations in homogeneous sets of establishments and facilities. Crime Prevention Studies, 21, 255-264. 
Englefield, A., \& Ariel, B. (2017). Searching for influential actors in co-offending networks: the recruiter. International Journal of Social Science Studies, 5(5), 24-45.

Freeman, L. (1977). A set of measures of centrality based on betweenness. Sociometry, 40, 35-41.

Haynie, D. L. (2001). Delinquent peers revisited: does network structure matter? American Journal of Sociology, 106, 1013-1057.

Home Office, (2001). Criminal justice: the way ahead. Cm 5074. London: Home Office.

Lantz, B., \& Hutchison, R. (2015). Co-offender ties and the criminal career: the relationship between cooffender group structure and the individual offender. Journal of Research in Crime and Delinquency, 52(5), 658-690.

Linton, B. (2016). Targeting criminal recruiters in London. Presented at the 9th International Conference on Evidence-Based Policing (12 July 2016, Cambridge, UK).

Macbeth, E. and Ariel, B. (2017). Place-based statistical versus clinical predictions of hotspots locations in Northern Ireland. Justice Quarterly. doi:https://doi.org/10.1080/07418825.2017.1360379

McCarthy, B., \& Hagan, J. (2001). When crime pays: Capital, competence, and criminal success. Social forces, 79(3), 1035-1060.

McCord, J. \& Conway, K. P. (2002). Patterns of juvenile delinquency and co-offending. In Crime and social organization (Vol. 10, pp. 15-30). Transaction Publishers New Brunswick, NJ.

McGloin, J. M., \& Kirk, D. S. (2010). An overview of social network analysis. Journal of Criminal Justice Education, 21(2), 169-181.

McGloin, J. M., Sullivan, C. J., Piquero, A. R., \& Bacon, S. (2008). Investigating the stability of co-offending and co-offenders among a sample of youthful offenders. Criminology, 46(1), 155-188.

Mitchell, R. J. (2017). The usefulness of a crime harm index: analyzing the Sacramento hot spot experiment using the California Crime Harm Index (CA-CHI). Journal of Experimental Criminology, 1-11.

Morselli, C. (2009). Inside criminal networks. New York: Springer.

Morselli, C., Tremblay, P., \& McCarthy, B. (2006). Mentors and criminal achievement. Criminology, 44(1), 17-43.

Newman, M. E. (2005). A measure of betweenness centrality based on random walks. Social Networks, 27(1), 39-54.

Norton, S., Ariel, B., Weinborn, C., \& O’Dwyer, E. (2018). Spatiotemporal patterns and distributions of harm within street segments: the story of the "harmspot". Policing: An International Journal, 41(3), 352-371.

Papachristos, A. V., Braga, A. A., Piza, E., \& Grossman, L. S. (2015). The company you keep? The spillover effects of gang membership on individual gunshot victimization in a co-offending network. Criminology, 53(4), 624-649.

Ratcliffe, J. H. (2015). Towards an index for harm-focused policing. Policing: A Journal of Policy and Practice, 9(2), 164-182.

Reiss, A. J., \& Farrington, D. P. (1991). Advancing knowledge about co-offending: results from a prospective longitudinal survey of London males. Journal of Criminal Law and Criminology, 82(2), 360-395.

Reiss, A. J., Jr. (1988). Co-offending and criminal careers. Crime and Justice, 10, 117-170.

Sandall, D., Angel, C. M., \& White, J. (2018). 'Victim-Offenders': a Third Category in Police Targeting of Harm Reduction. Cambridge Journal of Evidence-Based Policing, 2(3-4), 95-110.

Sherman, L. W. (2007). The power few: experimental criminology and the reduction of harm. Journal of Experimental Criminology, 3(4), 299-321.

Sherman, L. W., Gartin, P. R., \& Buerger, M. E. (1989). Hot spots of predatory crime: Routine activities and the criminology of place. Criminology, 27(1), 27-56.

Sherman, L. W., Neyroud, P., \& Neyroud, E. (2016). The Cambridge Crime Harm Index: measuring total harm from crime based on sentencing guidelines. Policing, 10(3), 171-183.

Sorensen, D.W.M. (2009). Trends in juvenile co-offending: Denmark 1981-2005. Report from Scandinavian Research Council for Criminology's 51st Research Seminar in Gilleleje, Denmark. 118-128.

Strang, S. (2009). Project SLEIPNIR: analytical technique for operational priority setting. Royal Canadian Mounted Police.

Tayebi, M., Bakker, L., \& Glässer, U. (2011). Locating central actors in co-offending networks. Proceedings - 2011 International Conference on Advances in Social Networks Analysis and Mining, ASONAM 2011, 171-179.

Van Mastrigt, S. B., \& Farrington, D. P. (2009). "Co-offending, Age, Gender and Crime Type: Implications for Criminal Justice Policy”. British Journal of Criminology, 49, 552-572.

Warr, M. (1996). Organization and instigation in delinquent groups. Criminology, 34, 11-37.

Warr, M. (2002). Companions in crime: the social aspects of criminal conduct. Cambridge: Cambridge University Press.

Wasserman, S., \& Faust, K. (1994). Social network analysis. Cambridge: Cambridge University Press.

Weerman, F. M. (2003). Co-offending as a social exchange. British Journal of Criminology, 43(2), 398-416.

Weinborn, C., Ariel, B., Sherman, L. W., \& O’Dwyer, E. (2017). Hotspots vs. harmspots: shifting the focus from counts to harm in the criminology of place. Applied Geography, 86, 226-244. 
Weisburd, D., \& Eck, J. E. (2004). What can the police do to reduce crime, disorder, and fear? The Annals of the American Academy of Political and Social Science, 593, 42-65.

Weisburd, D., \& Mazerolle, L. G. (2000). Crime and disorder in drug hotspots: implications for theory and practice in policing. Police Quarterly, 3(3), 331-349.

Zeng, J., Ustun, B., \& Rudin, C. (2017). Interpretable classification models for recidivism prediction. Journal of the Royal Statistical Society: Series A (Statistics in Society), 180(3), 689-722.

Zipf, G. (1949). Human behaviour and the principle of least effort: an introduction to human ecology. Cambridge, MA: Addison-Wesley Press.

Publisher's Note Springer Nature remains neutral with regard to jurisdictional claims in published maps and institutional affiliations.

Christian Frydensberg, MSt (Cantab), is a police inspector and analyst in the Danish Police's National Centre of Investigations (NCI), in Glostrup.

Barak Ariel , Ph.D., is a lecturer in Experimental Criminology at the University of Cambridge Institute of Criminology's Police Executive Programme, and associate professor at the Institute of Criminology, Hebrew University.

Matthew Bland, MSt (Cantab), is a Ph.D. candidate in the Jerry Lee Centre of Experimental Criminology, Institute of Criminology, University of Cambridge. He is also a research manager for the Cambridge Centre for Evidence-Based Policing.

\section{Affiliations}

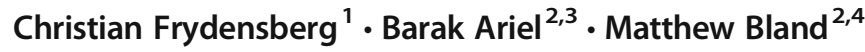

Matthew Bland

Matthew_Bland@outlook.com

1 Danish National Police, National Centre of Investigations (NCI), Glostrup, Denmark

2 Institute of Criminology, University of Cambridge, Sidgwick Avenue, Cambridge, UK

3 Institute of Criminology, Faculty of Law, Hebrew University, Jerusalem, Israel

4 Cambridge Centre for Evidence-Based Policing, Cambridgeshire, UK 